\title{
Relationship between Headmasters' Leadership, Task Load on Special Education Integration Programme Teachers' Job Satisfaction
}

\author{
Mohd Norazmi Bin Nordin*, Mohamad Zaid Bin Mustafa, Abdul Rasid Bin Abdul Razzaq \\ Faculty of Technical and Vocational Education, Universiti Tun Hussein Onn Malaysia, Malaysia
}

Received April 10, 2020; Revised May 5, 2020; Accepted June 16, 2020

Copyright $\mathrm{C} 2020$ by authors, all rights reserved. Authors agree that this article remains permanently open access under the terms of the Creative Commons Attribution License 4.0 International License

\begin{abstract}
The leadership of the headmaster at the school exerted a powerful influence on the overall management of the school. For schools with the Special Education Integration Program (SEIP), the leadership of the headmasters is affecting the task load of teachers and their productivity. The subsequent state of affairs also has an impact on job satisfaction. There have been numerous studies at home and abroad that have shown that headmaster leadership has a significant impact on SEIP teacher duties. This study was conducted to identify the relationship between headmaster leadership, task load and SEIP teacher job satisfaction. Data were collected quantitatively by distributing a set of questionnaires to 400 respondents comprising SEIP teachers throughout Malaysia using google form. Using Structural Equation Modeling (SEM) and AMOS software, all three constructs were tested to identify their relationships with each other. The analysis showed that there was a significant positive relationship between headmaster leadership, task load and SEIP teacher job satisfaction. There are many studies on these constructs, but the use of SEM analysis for related constructs is still poorly conducted. The findings of this study can serve as a reference to school administrators, especially principals to re-evaluate their leadership so as not to burden teachers and to provide job satisfaction to SEIP teachers.
\end{abstract}

Keywords Structural Equation Modelling, Headmaster Leadership, Task Load, Teacher Job Satisfaction, Special Education Integration Program

\section{Introduction}

The issue at SEIP is the burdensome task of special education teachers (Anderson, [1]). Norizan, Zahida and
Takwa [2] stated that these teachers carry a variety of tasks over a specific period. They are not only actively involved in teaching at SEIP, but are also embroiled in external assignments that do not involve special need student (SNS). This also underscores the need for teachers to have a better understanding of the difficulties faced by special education teachers in their efforts to educate SNS for job satisfaction (Junaidah \& Rosila, 2013) [3]. In general, the teachers' task load needs to be addressed as much as it will affect the job satisfaction of teachers and consequently SNS incarceration (Norizan et al., [2]; Junaidah \& Rosila, [3]). Rabayah, Zuri, Rahimi, Aznan, Zainudin, Hairulnizam and Aswati [4] explain that the high task load faced by SEIP teachers is a result of the lack of leadership. Massithah [5] in her study stated that tasks unrelated to special education or SNS caused the tasks to be carried out at one time. The most worrying is that this high burden of work has created pressure on SEIP teachers (Anderson, [1]). There is evidence on this issue in several other studies, including the study of Amalina and Azita [6], which found that the factors are closely related to the stress level of special education teachers. They say that this burden factor is also the highest factor that has put pressure on special education teachers. The study of Rahim, Johari, Jamaluddin and Musa [7] found that $48.17 \%$ of respondents agreed that special education teachers were burdened with a variety of school assignments which would ultimately affect the quality of the teaching process and job satisfaction of the teachers involved. The next is a study by Norizan et al., [2] which states that special education teachers not only need to carry out the teaching process in the classroom, but also engage in administrative work, discipline management, alternate teachers and many other tasks.

Other evidence is from studies by Norashid and Hamzah [8], Junaidah and Rosila [3], Abdillah and Woo [9] and Rabayah et al., [4] conclude that high task load 
among SEIP teachers exists because they have to deal with the task of dealing with mainstream students and at the same time they need to focus their attention on SEIP. Massithah [5] explains the convergence of two streams of students at once that increases the number of assignments. Erica and Raymond [10] also found that the focus on non-authentic work such as SEIP teachers towards SNS has become the norm of one's task load. Nelson, Melissa and Kathleen [11] state that special education teachers are given tasks that are inadequate to them such as administrative tasks as well as non-essential tasks such as replacing absent staff. At the same time, they also have to adhere to their true duties. Meanwhile, Junaidah and Rosila [3] stated that there is also situations where special education teachers are not given enough time to complete a task assigned. The time interval between assignments either involves the SNS or does not correspond to the intensity of work that needs to be met (Erica \& Raymond, [10]). These conditions can actually have a detrimental impact on health and work performance; if health condition is declining and concentration is impaired, the quality of work and job satisfaction will also be impaired (Nelson et al., [11]). Therefore, this study was conducted to examine the relationship between headmaster leadership, task load and SEIP teacher job satisfaction. There are also three research hypothesis stated.

Research Hypothesis:

$\mathrm{H}_{1}$ : Headmasters leadership had a significant positive relationship with teachers task load

$\mathrm{H}_{2}$ : Headmasters leadership had a significant positive relationship with teachers job satisfaction

$\mathrm{H}_{3}$ : Teachers task load had a significant positive relationship with teachers job satisfaction

\section{Literature Review}

Special education leadership is a comprehensive management aspect of special education operations that includes knowledge, leadership style and the well-being of teachers and students (Zharunizam, [12]). Good leadership for special education programs should carry out the planning, organizing, directing and controlling of organizational members and utilize all organizational resources to achieve the organizational goals specific to SEIP (Yokuno, [13]). Leaders who work in special education need to make the special education program better and function properly (Nadhir \& Alfa, [14]). Good leadership can also prevent high task loads (Zharunizam, [12]).

The burden of special education tasks occurs when teachers took on various tasks, whether related to special education or not at any given time (Norizan et al., [2]). Special education teachers at SEIP are forced to do assignments that are not related to SNS within the time they are supposed to teach SNS (Junaidah \& Rosila, [3]). Meanwhile, Anderson [1] stated that the burden of special education teachers' duties is that they are tasked with affecting their true role in teaching SNS. Rabayah et. al., [4] and Massithah [5] explain that the task load of special education teachers makes teachers dissatisfied with their teaching on SNS. The job satisfaction of a special education teacher can be enjoyed when the teacher is able to focus on the teaching of SNS and the student demonstrates appropriate discipline (Junaidah \& Rosila, [3]). This job satisfaction, if achieved, increases teachers' commitment to performing their tasks (Zulhairi, Jamalul \& Ruzita [15]). However, if job satisfaction is not achieved, then avoidance and neglect of responsibility will occur (Rosni, [16]). This job satisfaction is essential in producing the best possible productivity of special education teachers (Mollynda, [17]).

Mati and Kadi [18] in their study found that there was a significant relationship between headmasters' leadership with increasing task load of special education teachers and increasing levels of teacher effectiveness. The study of Junaidah and Rosila [3] involving 115 special education teachers in the state of Perlis showed little impact of the style of headmaster leadership on the task load of special education teachers. The results of Angela's [19] study identified five thematic categories that need attention of headmasters in handling teachers' task load, namely learning, collaboration, data analysis, service delivery planning and implementation, and personnel development. The study of Hussain, Saghir, Misbah, \& Ayesha [20] showed that the leadership style of the principals is a factor in SEIP teachers' job satisfaction. The findings of the study of Huang, Hashem, Azina \& Jasimah, [21] found that decision-making style plays an important role as a mediating factor between headmaster leadership style and teacher job satisfaction. The findings of Gwendolin's [22] study showed that there is a significant relationship between headmaster leadership style and teacher job satisfaction. The findings of the study Thusyanthini and Ravivathani [23] showed that autocratic leadership style negatively affects teacher job satisfaction, while democratic leadership style positively affects teacher job satisfaction.

In addition, the study by Norazmi, Zaid and Rasid [24] was conducted to determine whether headmasters leadership factors affect the task load of the SEIP teacher in Johor Malaysia. A fully quantitative method was used in this study by distributing a set of online questionnaires to SEIP teachers across Malaysia. The findings show that all the factors mentioned, namely, leadership style, attitude, knowledge, experience, and qualification are validated as influences on the SEIP teacher's task load. There have been several studies examining the leadership factor affecting the task load of the SEIP teacher, but the application of the CFA approach using AMOS is still underdeveloped. Therefore, the findings of this study can further confirm previous findings on this issue. This research can be useful for the headmaster and the SEIP teachers to give their best in school management. 
A full qualitative study by Norazmi [25] was conducted to identify factors affecting the task load of SEIP teachers in Johor, Malaysia. Through thematic analysis, the findings indicate that there are three factors contributing to the task load of SEIP teachers', namely students, facilities and leadership. This study also stated that the major factor for SEIP teachers task load is headmaster leadership. It also provides an indication that the problem of headmaster leadership has impacted the task load of teachers and hindered teacher job satisfaction. At the end of the study, the researchers suggested that the findings could serve as a guide for headmasters to manage SEIP in schools.

\section{Research Methodology}

This study uses the full quantitative method in data collection. Researchers distributed randomized sets of questionnaires to SEIP teachers through google form. There were 119 items submitted in the questionnaire. A total of 400 respondents answered the questionnaire completely and suitably for analysis. The data were then analyzed by CFA method using AMOS 21. The test is performed by combining all three constructs in one measurement model. Through these measurement models, the relationships between constructs are identified. The main criterion for determining this compatibility was to look at the positive factor loading value that should be $\geq$ 0.50 (Hair, Black, Babin \& Anderson [26]). For fitness index, the RMSEA value should be $\leq 0.08$ (Byrne, [27]), while the GFI, CFI and TLI values (one of them) should be $\geq 0.90$ (Bentler, [28]; Hatcher, [29]). Relative / Normed Chi-Square values must be approximately $\leq 5.0$ (Bentler, [28]). In order to verify the relationship among constructs, discriminant validity had been taken into account. Acceptable discriminant validity values were $<0.90$ (Fornell \& Larcker, [30]; Hair et al., [26]). In addition, significant values must be $<0.05$ to indicate acceptable values (Creswell, [31]).

\section{Findings}

As a result of the analysis done, this model did not reach the correct value of the compatibility due to item overlap and negative factor loading value. This gave an indication that the item was not significant and did not measure the relevant later construct (Bryne, [27]). Items that were in negative factor loading values, dropped because they impede the value of compatibility (Bahaman, [32]). Therefore, modifications were made to achieve this purpose. As a result of this study, it was found that 16 matching items underwent measurement overlap and one of them had to be dropped because of lower factor loading. Items dropped are BT002, BT015, BT017, BT018, BT026, BT028, КP042, КP044, КР046, КP052, КP062, КР077, KK092, KK096, KK115 and KK116. The model was re-analyzed and the results still did not reach the value of compatibility.

Modifications were underway and there were still overlapping items. The items were then looped to make the model more compatible. After a step-by-step looping process, the model was re-analyzed and successfully achieved a correlation index with Relative Chi-Square values $=2.319$, RMSEA $=0.58$ and $\mathrm{CFI}=0.903$. The results also indicated that each construct demonstrates a validity of discriminant validity of 0.89 for the matching of headmaster's leadership with the teacher's task load and the teacher's task load construct with the teacher's job satisfaction. Meanwhile, the headmasters' leadership with the teacher's job satisfaction ratio was 0.81 . To determine whether the relationship between constructs is significant, hypothesis testing was performed. Based on the three hypotheses set, tests were conducted to determine whether the hypothesis was acceptable or rejected. The summary of the test analysis of hypothesis as shown in Table 1.

Table 1. Hypothesis Test

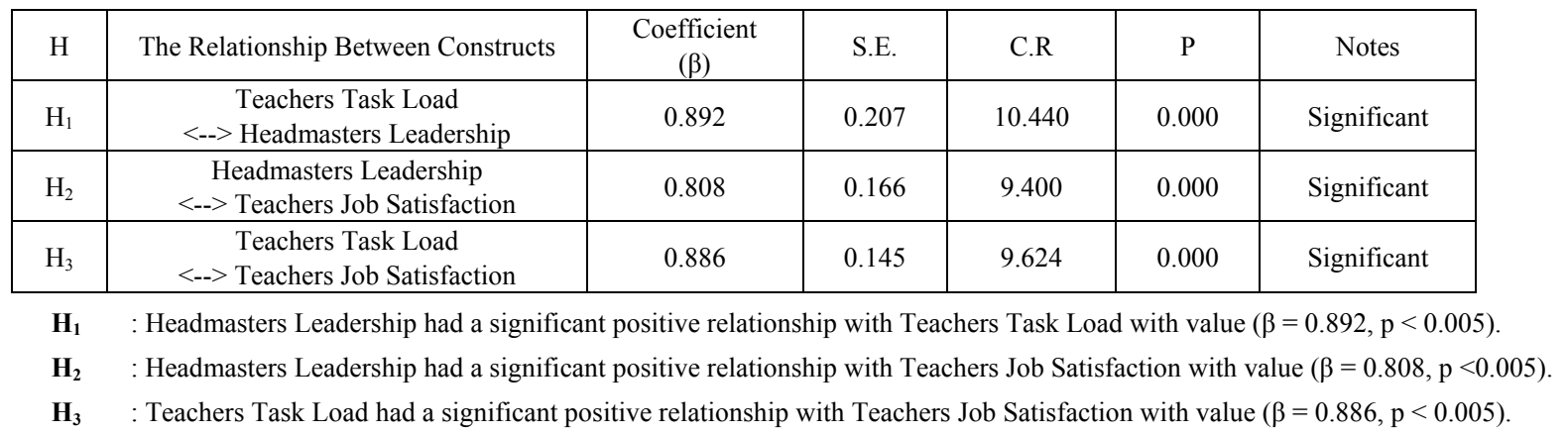




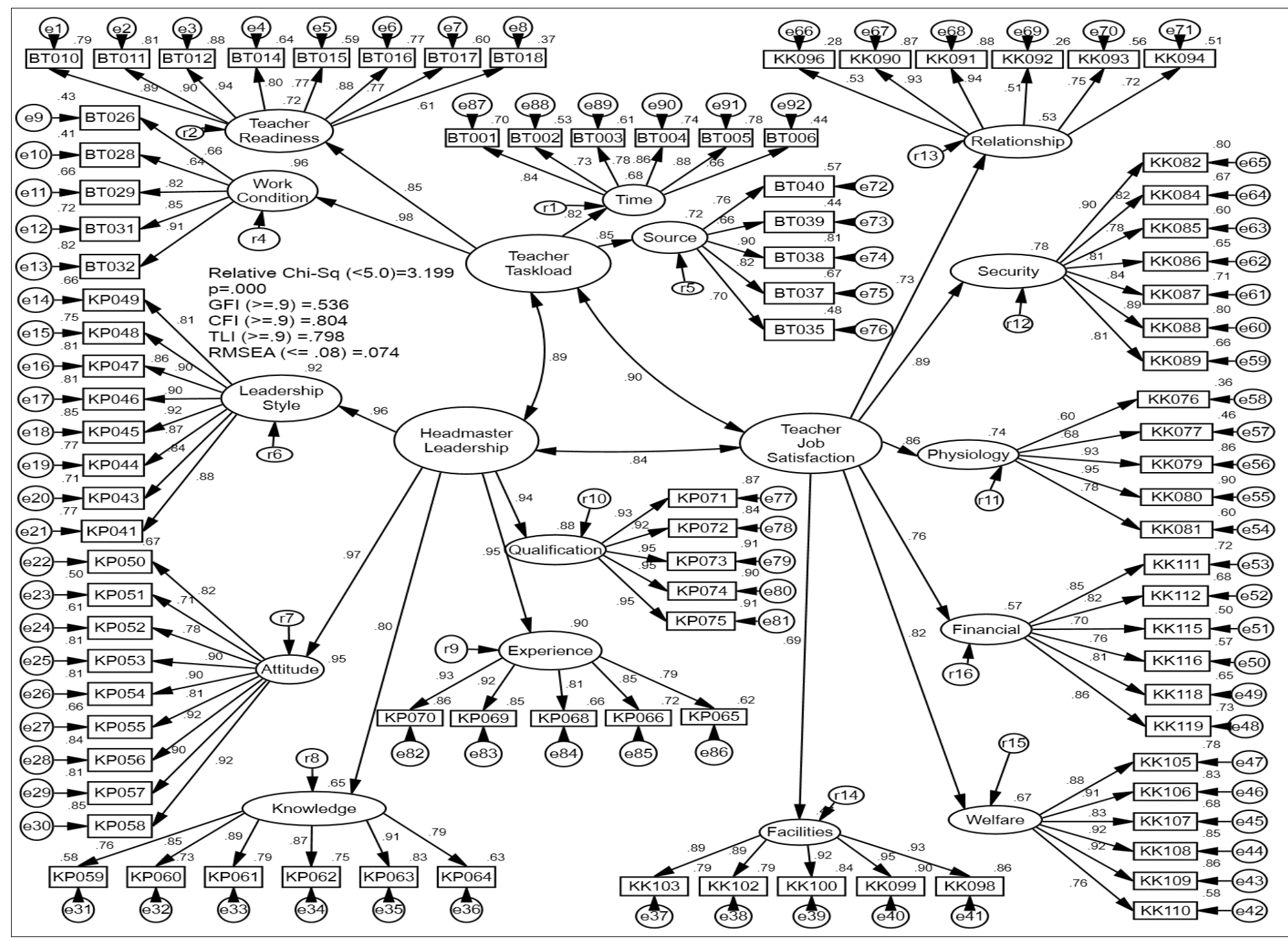

Figure 1. Pooled Measurement Model (Original) 


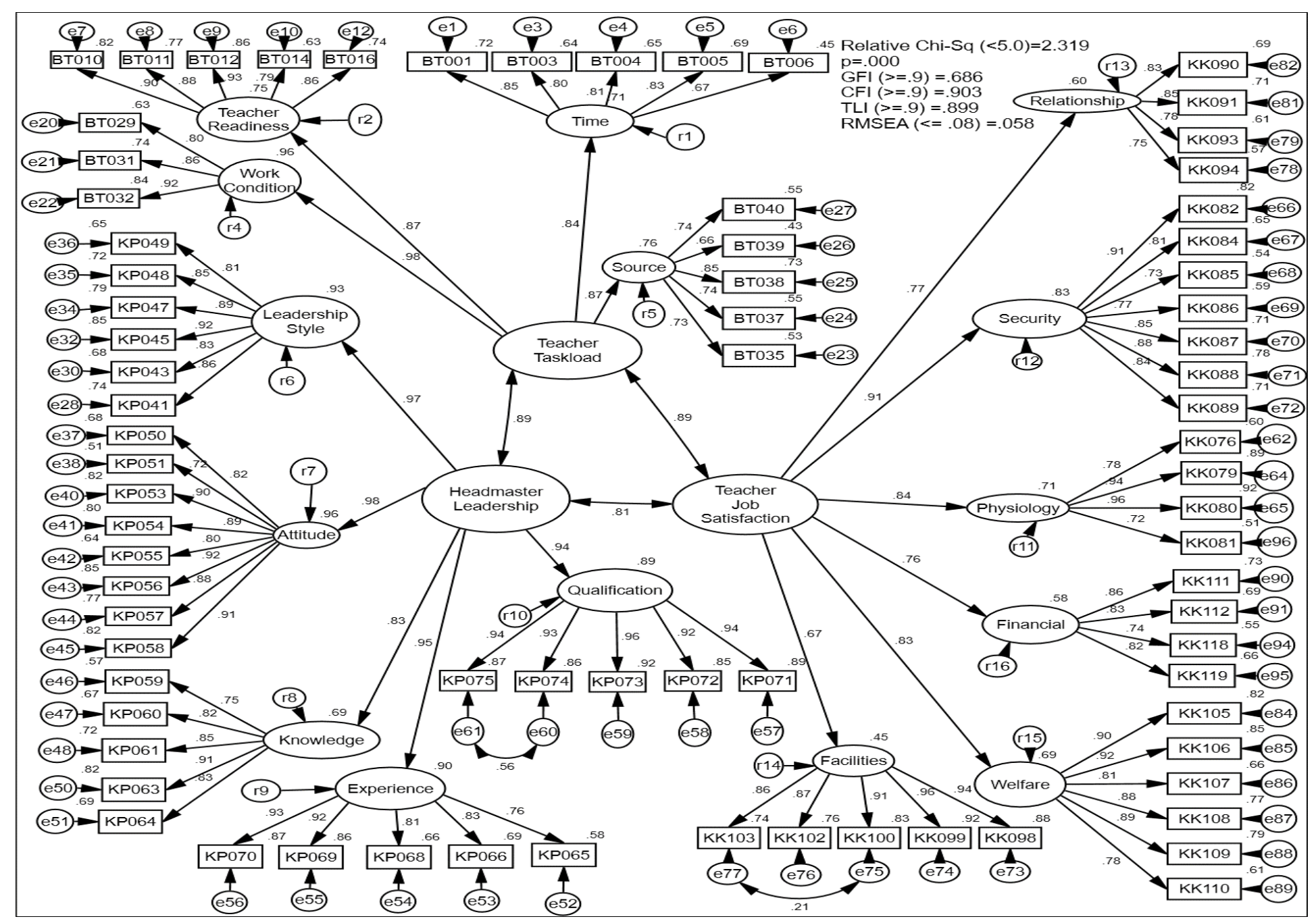

Figure 2. Pooled Measurement Model (Modified) 


\section{Discussion}

The results show that there is a significant positive relationship between the construct of the headmaster leadership on the teachers task load. This indicates that there is a significant direct relationship between the headmaster leadership and the burden of the SEIP teacher job. This finding supports the study by DiPaola and Walther-Thomas [33] who stated that principals held by headmaster were able to reduce the task load of SEIP teachers. Similarly, a study by Junaidah and Rosila [3] explains that headmasters leadership is a determinant of good SEIP management and is able to reduce the burden of SEIP teachers task load.

The result of this study found that there is a significant positive relationship between the construct of the headmasters leadership on teachers job satisfaction. This indicates that there is a significant direct relationship between headmasters leadership and SEIP teachers job satisfaction. The findings of this study are in line with the study by Angela [19] who stated that the headmasters leadership is capable of giving SEIP teachers the opportunity to do their work in a satisfactory and happy manner. Similarly, a study by Eytan [34] agreed that the headmasters leadership practices at SEIP can enhance the job satisfaction and productivity of SEIP teachers.

The results also revealed that there was a significant positive relationship between teachers task load constructs and job satisfaction of SEIP teachers. This indicates that there is a significant direct relationship between teachers task load and SEIP teachers job satisfaction. The findings of this study support the study by Rosnah and Fatihah [35] who found that task load is a factor in the performance of teachers in school. Amalina and Azita [6] also share the same view that SEIP teachers' task load can be reduced if the work environment and work conditions are improved. The findings also showed that headmasters need to make a strong commitment to their leadership in terms of knowledge, leadership style, attitude, experience and qualification. All of these elements were important in controlling the task load of teachers and also gave them a sense of satisfaction at work. As for the knowledge aspect, teachers need to find as much knowledge as possible about special education such as policies, special education fundamentals, management in special education, SNS requirements and classroom management for SNS. As for the aspect of leadership style, democratic style was seen as a better focus. That was because the democratic leadership style has provided an opportunity of discussion between headmasters and SEIP teachers. In addition, their attitude towards the existence of SEIP and awareness of the importance of equal education to SNS should also be noted. In terms of experience, the headmasters who lead in SEIP need to make sure they were able to be with SEIP and SNS regularly. This is for them to experience the teaching and management of SEIP and SNS. As for the qualification aspect, it means the academic level that the headmaster has achieved in enhancing SEIP management.

\section{Conclusions and Suggestions}

It can be concluded that to address the issue of high teachers task load and job satisfaction of SEIP teachers, headmasters need to practice leadership that is appropriate to the environment by which they are led. Principals should also have the attitude to understand the scope of SEIP teachers' tasks in more detail and equip themselves with adequate knowledge of special education, SNS and the scope of teacher assignments. If the task load of these SEIP teachers can be handled well, then they will be able to achieve their job satisfaction. This study also reveals the importance of effective leadership in ensuring the well-being of teachers. The best leadership can also assist the SNS in their academic achievement. The leadership of the principals who are affected by SEIP should be noted as it is able to control the task load of teachers and ensure job satisfaction for teachers in SEIP. The well-being of these teachers can have an impact on SNS achievement in schools. As a suggestion, it is proposed that this study be conducted qualitatively to obtain more research data.

\section{Acknowledgments}

The authors would like to thank Ministry of Education Malaysia for supporting this research under Fundamental Research Grant Scheme Vot No. K207, FGRS/1/2019/SS109/UTHM/02/1 and partially sponsored by Universiti Tun Hussein Onn Malaysia.

\section{REFERENCES}

[1] Anderson, J. (2017). A Workload Analysis Formula to Increase the Retention of Special Education Teachers in Minnesota. Culminating Projects in Special Education. 37.

[2] Norizan, A. G., Zahidah, A.M. \& Takwa, C. W. (2013). Teachers' Challenges in Educating Special Children in Special Classes of Three Selected Primary Schools, Kuala Terengganu, Terengganu, Malaysia. Advances in Natural and Applied Sciences, 7(3): 284-291, 2013.

[3] Junaidah, M. \& Rosila, N. Y. (2013). Kajian Tentang Kepuasan Bekerja Dalam Kalangan Guru-Guru Pendidikan Khas. Asia Pacific Journal of Educators and Education, Vol. 28:103-115.

[4] Rabayah, Y., Zuri, G., Rahimi, C. A., Aznan, C. A., Zainudin, M. I., Hairulnizam, I. \& Aswati, H. (2010). Stress Dalam Kalangan Guru Pendidikan Khas. Jurnal MEDC Volume 6 201: 1-11.

[5] Massithah (2009). Hubungan Pengajaran Guru Besar 
Dengan Komitmen Kerja Guru Di Sekolah Rendah Luar Bandar. The International Journal of Learning.Volume 16:21-29.

[6] Amalina, R. \& Azita, A. (2016). Faktor-Faktor Yang Mempengaruhi Tahap Stres Guru Pendidikan Khas. Active Online Journal, UTHM, 8, 1.

[7] Rahim, H., Johari, S., Jamaluddin, R. \& Musa, I. (2006). Tahap Minat, Pengetahuan Dan Kemahiran, Latihan Guru Dan Beban Tugas Guru Program Pemulihan Khas Sekolah Kebangsaan Daerah Pontian, Johor. Annual Conference on Teacher Education, 6-8 Sept 2006, Kota Kinabalu, Sabah.pp 18-23.

[8] Norashid, O. \& Hamzah, M. O. (2014). Beban Tugas Dan Motivasi Pengajaran Guru Di Sekolah Menengah Daerah Ranau. Journal for Educational Thinkers Vol. 5, pp. 35-57.

[9] Abdillah, R. \& Woo, S. F. (2010) Faktor-Faktor Yang Mendorong Tekanan Kerja (Stres) Di Kalangan Guru-Guru Sjk(C): Satu Kajian Di Tiga Buah Sekolah Di Wilayah Persekutuan. Faktor-Faktor Yang Mendorong Tekanan Kerja (Stres) Di Kalangan Guru-Guru Sjk(C): Satu Kajian Di Tiga Buah Sekolah Di Wilayah Persekutuan, pp. 1-12.

[10] Erica, N. \& Raymond, L. C. (2009). Special Education Teacher Retention and Attrition: The Impact of Increased Legal Requirements. International Journal of Educational Management, Vol. 23 Issue: 5, pp.431-440.

[11] Nelson C. B., Melissa A. S. \& Kathleen Lynne Lane, (2014). Special Education Teacher Burnout: A Synthesis of Research from 1979 to 201. Education and Treatment of Children, Volume 37, Number 4, November 2014, pp. 681-711.

[12] Zharulnizam, Z. A (2010). Kepimpinan Dan Pengurusan Pendidikan Khas. Kuala Lumpur: Utusan Publications \& Distributors.

[13] Yokuno, A. (2019). Pengurusan dan Pentadbiran Pendidikan Khas. Retrieved at 27 April 2019, from https://www.scribd.com/doc/174444492/pengurusan-dan-p entadbiran-pendidikan-khas

[14] Nadhir, M. A. N. \& Alfa, N. A. (2016). Special Education for Children with Disabilities in Malaysia: Progress and Obstacles. Malaysian Journal of Society and Space 12 issue 10: $78-87$.

[15] Zulhair, I., Jamalul, A. W. \& Ruzita, M. H. (2016). Kepuasan Kerja Guru dan Perbezaannya Berdasarkan Pencapaian Sekolah. Jurnal Personalia Pelajar 19(1) (2016): 49-54.

[16] Rosni, R. (2014). Stres Dan Kepuasan Kerja Guru Pendidikan Khas Di Daerah Johor Bahru. Universiti Teknologi Malaysia: Master Thesis.

[17] Mollynda (2013). Tekanan Dan Kepuasan Kerja Dalam Kalangan Guru Pendidikan Khas Program Integrasi Bermasalah Pembelajaran Sekolah Rendah Di Zon Pantai Barat Utara. Sabah: Universiti Malaysia Sabah.

[18] Mati, H. \& Kadi, L. (2014). School Principals' Leadership Styleand Teachers' Subjective Well-Being at School. Problems of Education In The 21st Century Volume 62, 2014: 40-50.
[19] Angela, B. D. (2010). Principal Leadership for Special Education: Perceptions of Principals and Directors of Special Education. Directed by Dr. Carl Lashley. 200 pp.

[20] Hussain, C., Saghir, A., Misbah, M. \& Ayesha, B. (2017). Principals' Leadership Styles and Teachers' Job Satisfaction: A Correlation Study at Secondary Level. Bulletin of Education and Research December 2017, Vol. 39, No. 3 pp. 45-56.

[21] Huang, H., Hashem, S. J., Azina, I. \& Jasimah, W. A. R. (2013). Principal's Leadership Style and Teacher Job Satisfaction: A Case Study in China. Interdisciplinary Business Research August 2013 VOL 5, NO 4: 175-184.

[22] Gwendolin J. S. (2017). The Relationship between Teacher Job Satisfaction And Principal Leadership Styles. Carson-Newman University: Disertasi Kedoktoran.

[23] Thusyanthini, N. \& Ravivathani, T. (2014). The Inflence of Principals' Leadership Styles on School Teachers' Job Satisfaction-Study of Secondry School In Jaffna District. International Journal of Scientific And Research Publications, Volume 4, Issue 1, January 2014: 1-7.

[24] Norazmi, N., Zaid, M. \& Rasid, A. R. (2020). Special Education Integration Program (PPKI) Teachers: Task Load and Job Satisfaction. International Journal of Psychosocial Rehabilitation, Vol. 4, Issue 7: 7439-7445.

[25] Norazmi, N. (2020). Factors for the Task Load of Special Education Integration Program (PPKI) Teachers in Johor. International Journal of Innovative Technology and Exploring Engineering (IJITEE), Volume 9, Issue 3: 2413-2416.

[26] Hair, J. F., Black, W. C., Babin B. J., \& Anderson, R. E. (2010). Multivariate Data Analysis $\left(7^{\text {th }} E d\right)$. Englewood Cliffs: Prentice Hall.

[27] Byrne, B. M. (2010). Multivariate applications series. Structural equation modeling with AMOS: Basic concepts, applications, and programming (2nd ed). New York, NY, US: Routledge/Taylor \& Francis Group.

[28] Bentler, P. M. (1990). Comparative fit indexes in structural models. Psychological Bulletin, 107(2), 238-246. http://dx.doi.org/10.1037/0033-2909.107.2.238

[29] Hatcher, L. (1994) A Step-by-Step Approach to Using the SAS System for Factor Analysis and Structural Equation Modeling. SAS Institute, Inc., Cary.

[30] Fornell, C. D., \& Lacker, D. F. (1981). Evaluating Structural Equation models with Unobservable Variables and Measurement Error. Journal of Marketing Research, 18, 39-50. http://dx.doi.org/10.2307/3151312

[31] Creswell, John W. (2012). Educational Research: Planning, Conducting and Evaluating Quantitative and Qualitative Research. $4^{\text {th }}$ Edition. USA: Pearson Education Inc.

[32] Bahaman (2016). Enhancing Extension Education Research using Structural Equation Modeling Enriching Evidence-Based Extension Work Practices. Serdang: Universiti Putra Malaysia Press.

[33] DiPaola, M. F. \& Walther-Thomas, C. (2003). Principals and Special Education: The Critical Role of School 
Leaders (COPPSE Document No. IB-7). Gainesville, FL: University of Florida, Center on Personnel Studies in Special Education.

[34] Eytan, C. (2015). Principal Leadership Styles and Teacher and Principal Attitudes, Concerns and Competencies regarding Inclusion. 5th World Conference on Learning, Teaching and Educational Leadership, WCLTA 2014
Procedia - Social and Behavioral Sciences 186 (2015): $758-764$.

[35] Rosnah, I. \& Fatihah, R. (2018). Prestasi Kerja Guru Dan Hubungannya Dengan Faktor Beban Tugas, Persekitaran Kerja Dan Personal: Kajian Kes Di Sebuah Sekolah Di Sabah. Jurnal Kepimpinan Pendidikan. Januari 2018, Bil. 5, Isu 1:60-71. 